\title{
Spawanie elektronowe $w$ ciśnieniu zredukowanym Innowacyjna metoda spawania słupów elektrowni wiatrowych
}

\author{
Reduced pressure electron beam welding \\ Innovative offshore wind turbines monopile welding method \\ in terms of the characteristics of the joint
}

\section{Streszczenie}

W artykule przedstawiono system do spawania wiązką elektronów w ciśnieniu zredukowanym słupów elektrowni wiatrowych.

Słowa kluczowe: spawanie elektronowe, złącza doczołowe, siłownia wiatrowa

\section{Perspektywy rozwoju energetyki wiatrowej w Polsce i na świecie}

Unia Europejska zakłada, że do 2030 r. OZE (Odnawialne Źródła Energii) będą wytwarzać $27 \%$ łącznej ilości energii zużywanej w Państwach Członkowskich. W Europie morska energetyka wiatrowa (MEW) rozwija się bardzo dynamicznie i tworzy nowy, obiecujący rynek. Europejskie Stowarzyszenie Energetyki Wiatrowej prognozuje, że w roku 2020 moc zainstalowana morskich farm wiatrowych w Europie może wynieść $40 \mathrm{GW}$, a w roku 2030 nawet $150 \mathrm{GW}$. Według danych brytyjskich w najbliższych latach tylko wzdłuż wybrzeża Anglii i Szkocji zamontowanych zostanie ponad 10000 elektrowni wiatrowych.

W 2015 r. łączna moc zainstalowana farm wiatrowych w Polsce wyniosła ponad $5 \mathrm{GW}$, co oznacza przyrost o niemal 1,3 GW (35\%). Dodatkowo, od stycznia do grudnia farmy wiatrowe wyprodukowały rekordowe ponad 10 TWh energii elektrycznej (TWh = Terawatogodzina). Polska posiada jeden z największych potencjałów w zakresie rozwoju morskiej energetyki wiatrowej na Morzu Bałtyckim. Szacuje się, że do 2030 r. moc zainstalowana morskich farm wiatrowych w Polsce osiągnie 6 GW. Polska może stać się jednym z kluczowych punktów w łańcuchu dostaw dla branży morskiej energetyki wiatrowej w Europie. Krajowi i zagraniczni przedsiębiorcy chcą wybudować w polskich obszarach morskich pięć dużych elektrowni wiatrowych. Najbardziej ambitne plany ma państwowa Polska Grupa Energetyczna, która do 2020 r. planuje budowę morskich farm wiatrowych o mocy $1 \mathrm{GW}$. Przewidywalne nakłady na inwestycję w perspektywie 11 lat to ok. 13,4 mld złotych.
Eksperci są przekonani, że farmy na morzu będą przyszłością energetyki wiatrowej. Ludzie nie chcą widzieć w swojej najbliższej okolicy turbin, dlatego trzeba będzie odejść z farmami wiatrowymi jak najdalej w morze.

Typowa przybrzeżna turbina wiatrowa o mocy $5 \mathrm{MW}$ wymaga pala fundamentowego o średnicy 5 metrów i długości 60 metrów ze stali o grubości blachy $100 \mathrm{~mm}$. Każda wieża waży około 750 ton i zawiera ok. 450 metrów długości spoin. Cykl produkcyjny tych wież ma główny wpływ na koszt i pracochłonność projektu. [4]

\section{Sytuacja w sektorze na świecie}

$369,6 \mathrm{GW}$ - globalna moc farm wiatrowych na koniec $2014 \mathrm{r}$,

51,4 GW - nowe przyłączenia farm wiatrowych w 2014 r., $44 \%$ - przyrost nowych przyłączeń względem roku poprzedniego.

Liderami pod względem popularności energetyki wiatrowej w 2014 roku były:
- Chiny
- 114,6 GW (31,0\% udziału)
- USA
- 65,9 GW (17,8\%udziału)
- Niemcy
- 39,2 GW (10,6\% udziału)
- Europa - 128,8 GW (35,0\% udziału)
<Źródło: Global Wind Energy Council (GWEC)>

\section{Sytuacja w Polsce}

- $23,4 \%$ - przyrost produkcji energii elektrycznej z farm wiatrowych,

- 5 miejsce w Europie pod względem nowych przyłączeń,

- 9 miejsce w Europie pod względem całkowitej mocy farm wiatrowych.

$<$ Dane za rok 2014> [4]

Inż. Mirosław Nowak (IWE); Marcin Nowak - Technika Spawalnicza Sp. z o.o.; dr inż. Alan Philips - Cambrige Vacuum Engineering

Autor korespondencyjny/Corresponding author: miroslaw.nowak@techspaw.com.pl 


\section{Sytuacja w Europie}

\section{Europejski system elektroenergetyczny}

910,1 GW - całkowita moc elektrowni konwencjonalnych i OZE

$14,8 \mathrm{GW}$ całkowity przyrost mocy w systemie,

w tym:

11,4 GW przypadło na energetykę wiatrową,

$13,1-18,7$ mld euro wynosiła wartość inwestycji.

$29,4 \%$ nowych mocy przypadało na energetykę wiatrową. $<$ Dane za rok 2014> [4]

\section{Polska}

Krajowa energetyka w coraz większym stopniu zmniejsza zależność od tradycyjnych paliw kopalnych.

- $86 \%$ produkcji energii elektrycznej w 2014 roku wyprodukowały konwencjonalne elektrownie wykorzystujące węgiel kamienny i brunatny.

- Przyrost produkcji energii elektrycznej odnotowano jedynie w przypadku produkcji energii z wiatru (wzrost o $23,4 \%$ ) oraz elektrowni gazowych (wzrost o $4,0 \%$ ).

\section{Farmy wiatrowe w Polsce}

38,1 GW - całkowita moc zainstalowana w Krajowym Systemie Elektroenergetycznym (spadek o 0,29 GW) w 2014 roku. Elektrownie wiatrowe są głównym źródłem energii elektrycznej wśród OZE, wyprzedzając te oparte o biomasę.

Ok. $5 \mathrm{GW}$ - łączna moc farm wiatrowych w Polsce, VI 2015 r. 1,0 GW - elektrownie oparte o biomasę, VI 2015.

444,3 MW - moc farm wiatrowych przyłączona w 2014 roku. 7,2 TWh - produkcja energii elektr. przez źródła wiatrowe 158,7 TWh - całkowita produkcja energii elektrycznej. [4]

W Polsce w 2014 roku na rzecz energetyki wiatrowej pracowało 8,4 tys. osób, z czego 3,4 tys. miejsc pracy powstało $w$ bezpośrednim otoczeniu branży. Dla porównania w przemyśle cementowym pracuje w Polsce ok. 6 tys. osób, a w rafineryjnym 9 tys. osób.

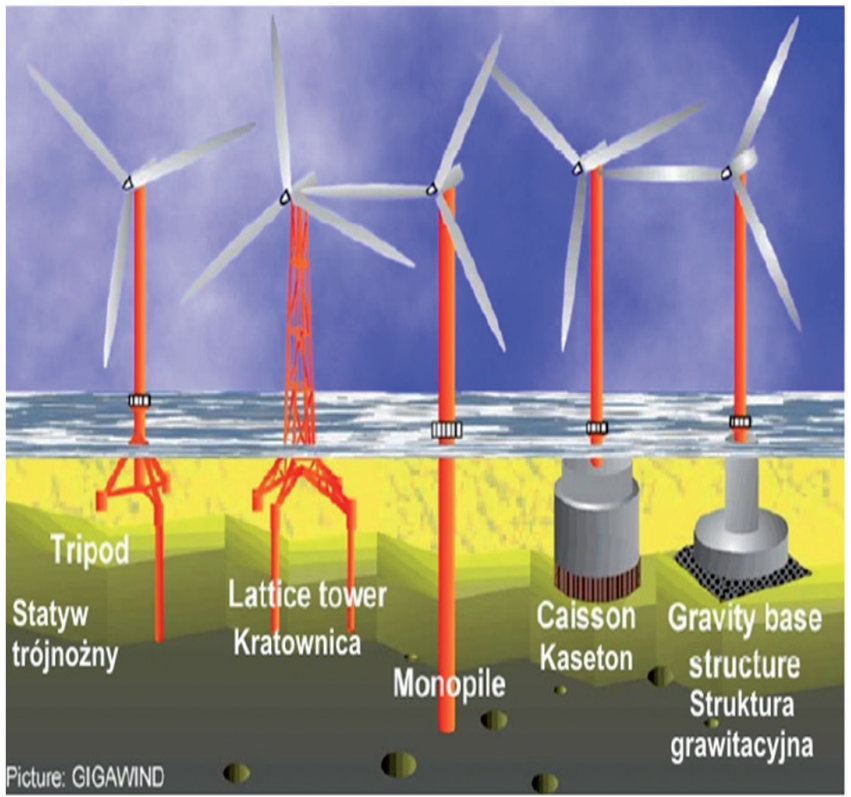

Rys. 1. Rodzaje morskich elektrowni wiatrowych

Fig. 1. Offshore wind turbines types

\section{Spawanie elektronowe w ciśnieniu zredukowanym RPEBW}

\section{Spawanie elektronowe EBW - rys historyczny}

Skoncentrowanej wiązki elektronów użyto po raz pierwszy do spawania w komorze próżniowej w latach 50 ubiegłego wieku w Niemczech i we Francji.

J.A. Stohr z francuskiej Komisji Energii Atomowej publicznie przedstawił proces spawania elektronowego w dniu 23 li- stopada 1957 r. Niemiecki fizyk Karl-Heinz Steigerwald prowadził pierwsze eksperymenty za pomocą zbudowanej w $1952 \mathrm{r}$. spawarki elektronowej. W 1958 r., spawając stop cyrkonu o grubości $5 \mathrm{~mm}$, odkrył tzw. efekt głębokiego wtopienia.

Pierwsze polskie spawarki elektronowe zostały opracowane:

- w 1970 r. w Przemysłowym Instytucie Elektroniki w Warszawie - spawarka uniwersalna typu EUS 6/25

- w 1971 r. w Instytucie Technologii Elektronowej Politechniki Wrocławskiej - spawarka uniwersalna EUS-1

W pierwszej połowie lat $70 \mathrm{w}$ przemyśle amerykańskim pracowało 700 spawarek produkcyjnych, w Japonii 70, w Niemczech i Anglii 100, we Francji 80, a w Polsce 5 laboratoryjnych spawarek elektronowych. W 2004 r. w kraju pracowało 15 spawarek [1].

Spawanie wiązką elektronów przeżywało burzliwy rozwój w latach siedemdziesiątych. Lata następne to ciągłe doskonalenie urządzeń i technologii spawania. Urządzenia stawały się coraz lepsze technicznie, wręcz wyrafınowane. Na świecie pracuje dziś ok. 3500 spawarek, w tym w Niemczech ok. 250, a w Polsce ok. 30.

Spawanie elektronowe jest procesem łączenia metali realizowanym przez bombardowanie styku łączonych elementów wiązką elektronów o dużej gęstości energii, poruszających się z wysoką prędkością (ok. 200 km/s w próżni). Prawie natychmiastowa zamiana energii kinetycznej elektronów na ciepło $\mathrm{w}$ miejscu zderzenia z powierzchnią spawanego przedmiotu powoduje lokalne stopienie materiału i wytworzenie spoiny po jego ponownym zakrzepnięciu. Proces kształtowania spoiny jest dwuetapowy: w pierwszym powstaje kanał wskutek bezpośredniego oddziaływania wiązki elektronów; w drugim - strumień ciekłego metalu powoduje zmianę rozmiarów kanału, głównie w górnej części (rys. 2).

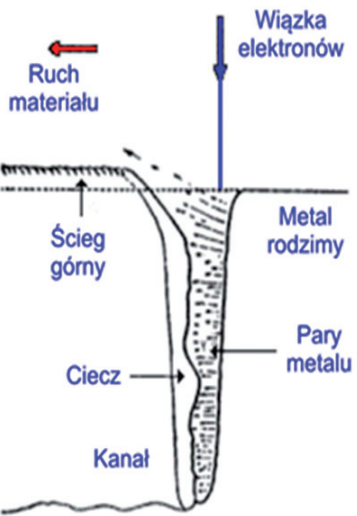

Rys. 2. Dwuetapowy proces kształtowania się spoiny Fig. 2. Two-step process of weld forming

Urządzenia do spawania wiązką elektronów niezależnie od wielkości i przeznaczenia składają się z pięciu podstawowych zespołów funkcjonalnych :

- układu próżniowego (od $10^{-2}$ do $10^{-5} \mathrm{mbar}$ )

- generatora wiązki elektronów

- bloku roboczego

- systemu sterowania

- systemu monitorowania

Wiązka elektronów o określonym natężeniu prądu, regulowanym przez potencjał elektrody sterującej, jest przyspieszana $\mathrm{w}$ polu elektrostatycznym między katodą i anodą, a następnie ogniskowana w polu magnetycznym cewki ogniskującej i odchylana (jeśli zachodzi potrzeba) dynamicznie lub statycznie $w$ polu magnetycznym cewek odchylających. Wytworzona i uformowana w ten sposób w dziale elektronowym wiązka elektronów trafia w obszar komory roboczej i pada na powierzchnię spawanego elementu, który jest mocowany w specjalnych uchwytach i wykonuje zazwyczaj ruch roboczy. Schemat budowy urządzenia elektronowego przedstawiono na rysunku 3. Spawanie elektronowe, w zależności od gęstości mocy, może być 
prowadzone tzw. techniką z jeziorkiem (nagrzewanie metalu spawanego jak w klasycznym procesie spawania łukowego z utworzeniem płytkiego jeziorka spawalniczego) lub znamienną dla tego procesu tzw. techniką z oczkiem (utworzenie głębokiego kanału gazodynamicznego „oczka”), zazwyczaj z przetopieniem materiału na wskroś. [2]

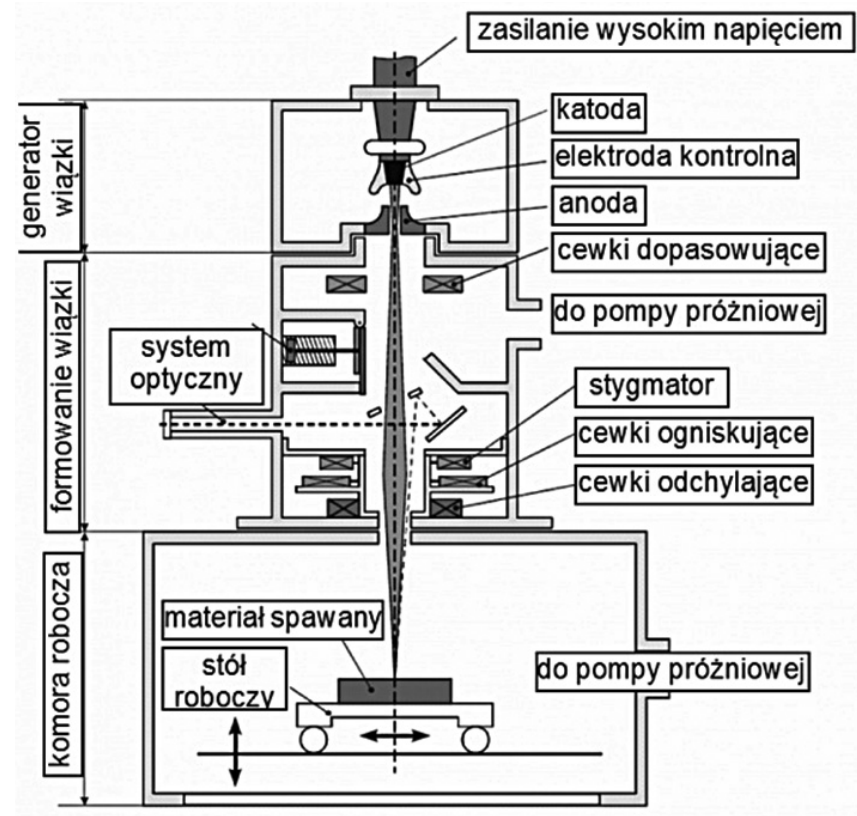

Rys. 3. Budowa spawarki elektronowej

Fig. 3. Structure of electron welder

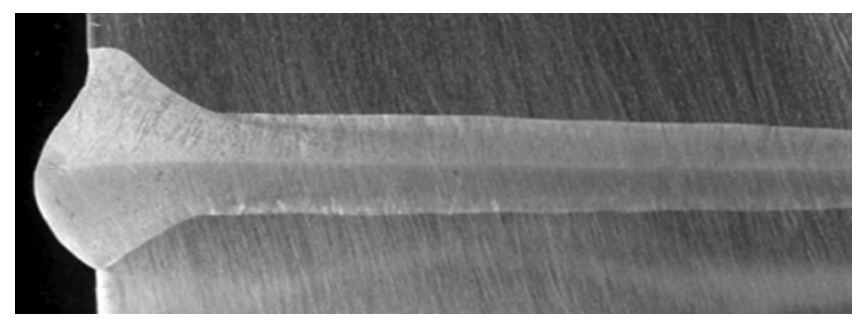

Główne cechy spawania elektronowego EBW:

- wąski ścieg spoiny

- wąska strefa wpływu ciepła

- niewielkie odkształcenie elementów

- niewielka ilość ciepła wprowadzonego do materiału

- czysta, nieutleniona powierzchnia

- możliwość łączenia różnych „trudnych" materiałów

W konwencjonalnym spawaniu elektronowym uzyskanie wysokiej jakości spoin wiąże się koniecznością umieszczenia elementów spawanych w specjalnych komorach próżniowych co ogranicza metodę do spawania elementów o niewielkich gabarytach. Przy spawaniu dużych elementów stalowych, koszty procesu rosną z uwagi na konieczność wytworzenia wysokiej próżni w komorach o dużych objętościach (rys. 4) [3].

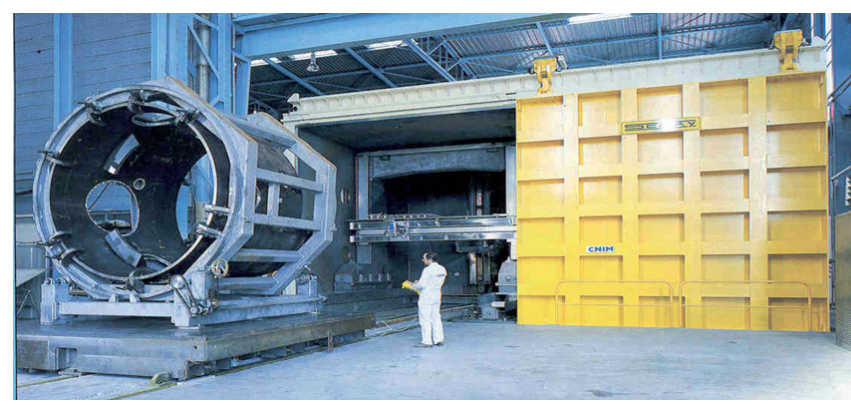

Rys. 4. Przykładowa komora $\left(230 \mathrm{~m}^{3}\right)$

Fig. 4. Chamber sample $\left(230 \mathrm{~m}^{3}\right)$
Spawanie elektronowe w ciśnieniu zredukowanym RPEBW (Reduced Preasure Electron Beam Welding)

Im gabaryty detali są większe tym większe są koszty uzyskania odpowiedniej próżni w komorze, dlatego specjaliści z CVE wspólnie z naukowcami z TWI opracowali metodę RPEBW.

Zalety spawania metodą RPEBW w stosunku do EBW:

- typowy system RPEBW wytwarza ściśle kontrolowaną wiązkę umożliwiającą spawanie elementów o grubości w zakresie 50 do 100 mm (rys. 5)
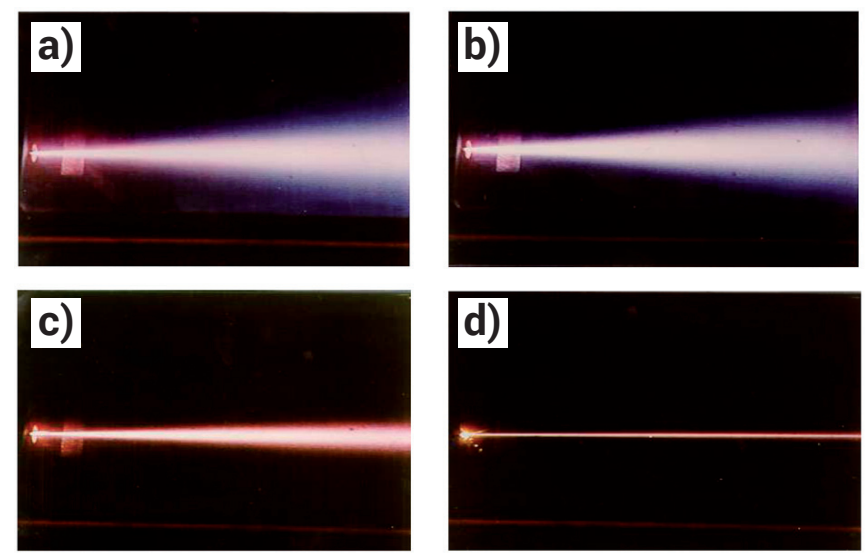

Rys. 5. Kształtowanie się promienia wiązki w zależności od ciśnienia i napięcia: a) $900 \mathrm{mbar}, 200 \mathrm{kV}, 300 \mathrm{~mA}$, hel; b) $700 \mathrm{mbar}, 200 \mathrm{kV}, 300$ $\mathrm{mA}$, hel; c) $60 \mathrm{mbar}, 200 \mathrm{kV}, 300 \mathrm{~mA}$, hel; d) $5 \mathrm{mbar}, 200 \mathrm{kV}, 300 \mathrm{~mA}$, hel Fig. 5. Forming of beam, depending on preassure and voltage: a) $900 \mathrm{mbar}, 200 \mathrm{kV}, 300 \mathrm{~mA}$, hel; b) $700 \mathrm{mbar}, 200 \mathrm{kV}, 300 \mathrm{~mA}$, hel; c) $60 \mathrm{mbar}, 200 \mathrm{kV}, 300 \mathrm{~mA}$, hel; d) $5 \mathrm{mbar}, 200 \mathrm{kV}, 300 \mathrm{~mA}$, hel

- praca w niskiej próżni znacząco redukuje czas jej uzyskania (o ok. 75\% przy użyciu standardowych pomp)

- komora zaciskowa jest elastyczna, umożliwia zastosowanie ruchomych uszczelnień w aplikacjach wymagających ciągłego spawania na rurach i powierzchniach płaskich

- wydłużona jest żywotność i stabilność katody

- proces umożliwia instalację lokalnych pomp i uszczelnień

- metoda umożliwia spawanie elektronowe wielkogabarytowych elementów

- możliwość spawania wiązką elektronów na miejscu budowy, rozszerzenie możliwości zastosowań przy znacznym obniżeniu kosztów wytwarzania

- spoiny są powtarzalnej jakości jak przy spawaniu elektronowym w wysokiej próżni

- spoiny są wolne od wtrąceń atmosferycznych

Podstawowe różnice między spawaniem elektronowym (EBW) a spawaniem elektronowym ze zredukowanym ciśnieniem (RPEBW) są następujące:

- w metodzie RPEBW nie ma próżniowej komory roboczej. W komorze roboczej panuje ciśnienie od $10^{-1}$ do 10 mbar. W technologii RPEBW podczas procesu spawania pompy podtrzymują ciśnienie w komorze roboczej

- działo elektronowe do technologii RPEBW posiada inną budowę szczególnie w rozmieszczeniach dysz i cewek korygujących.

Metoda spawania wiązką elektronów RPEBW została oceniona i przetestowana $\mathrm{w}$ wielu zastosowaniach. Proces ma ogromne znaczenie dla tych gałęzi przemysłu, które wykorzystują elementy wielkogabarytowe ze stali i innych metali nieżelaznych jak np. miedzi. Pierwszą aplikacją spawania metodą RPEBW w świecie było wdrożenie w szwedzkiej firmie SKB, która umieszcza odpady jądrowe w specjalnych kanistrach miedzianych (rys. 7).

Wykonane technologią RPEBW kanistry o średnicy 1 metra i długości 5 metrów są następnie umieszczane w skalnym podłożu na głębokości 500 metrów (rys. 8). Grubość ścianki i wieka kanistra wynosi po $50 \mathrm{~mm}$. 


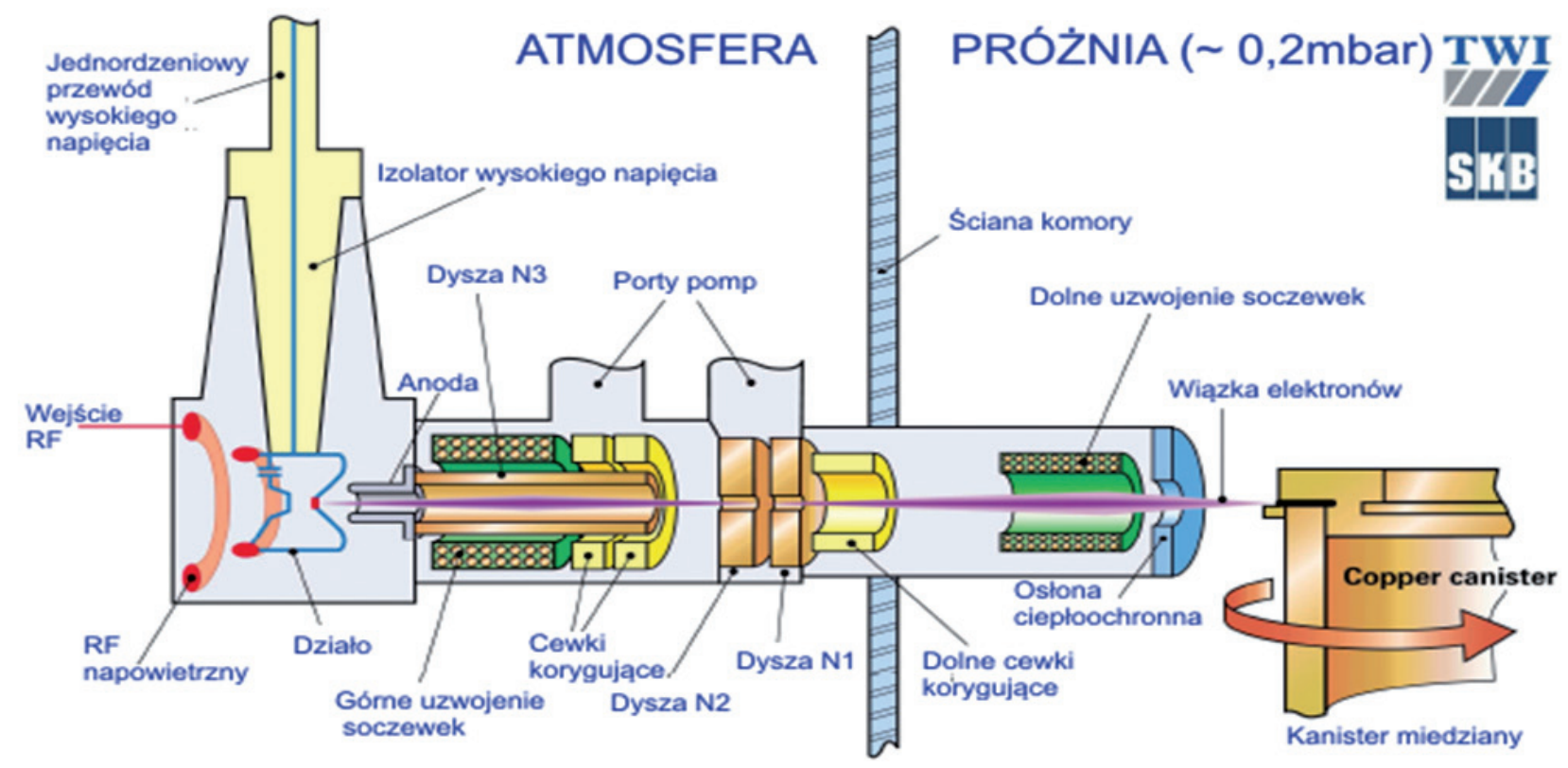

Rys. 6. Zasada spawania elektronowego w ciśnieniu zredukowanym RPEBW

Fig. 6. Electron beam welding in reduced preassure RPEBW

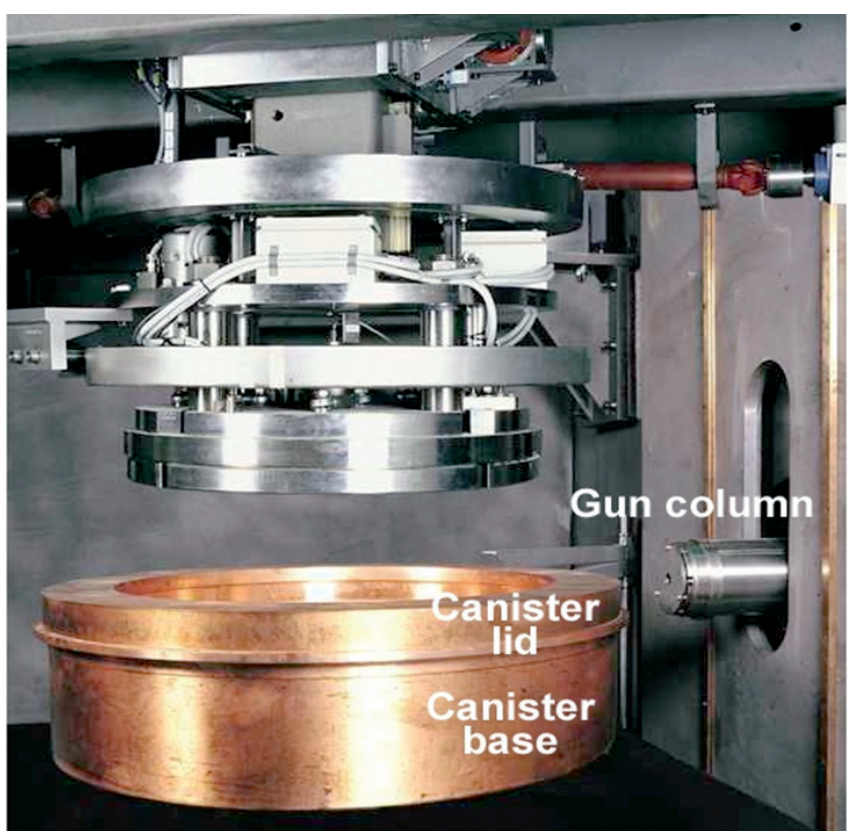

Rys. 7. Metoda zamykania kanistrów na odpady radioaktywne Fig. 7. Method of sealing of radioactive waste
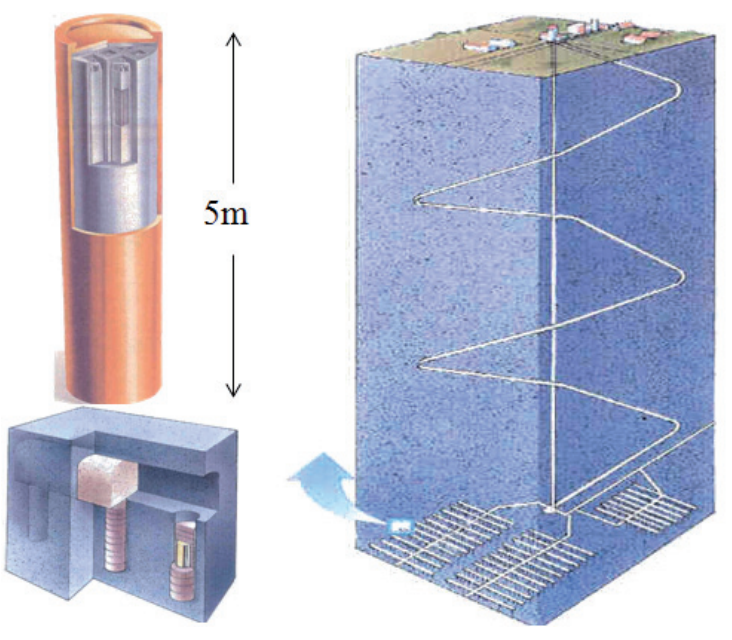

Rys. 8. Metoda zamykania kanistrów na odpady radioaktywne Fig. 8. Method of sealing of radioactive waste
Z uwagi na promieniotwórczość odpadów proces jest całkowicie zautomatyzowany. Firma gwarantuje żywotność kanistra na minimum sto tysięcy lat. Ważnym jest fakt, że spoina wykonana w technologii RPEBW eliminuje proces odgazowywania jaki towarzyszyłby tradycyjnym technologiom.

Dotychczas wiodącą technologią wykonywania słupów elektrowni wiatrowych jest spawanie łukiem krytym pod topnikiem. W technologii RPEBW stosuje się identyczne jak przy spawaniu łukiem krytym urządzenia peryferyjne takie jak pozycjonery, obrotniki czy słupowysięgniki. Największą trudnością jest specjalne wykonanie tzw. lokalnych uszczelnień zarówno do spawania wzdłużnego jak i obwodowego (Rys. 9,10,11,12).

Od konstrukcji wymienionych uszczelnień zależy praca pomp, które podtrzymują ciśnienie.

W połączeniu z technikami szybkiego zaciskania komór na średnicach zewnętrznych i wewnętrznych elementów kołowych a także $z$ uwagi na możliwość stosowania lokalnego przesuwnego uszczelnienia na elementach spawanych wzdłużnie metodą RPEBW staje się innowacyjną aczkolwiek kosztowną technologią wytwarzania.

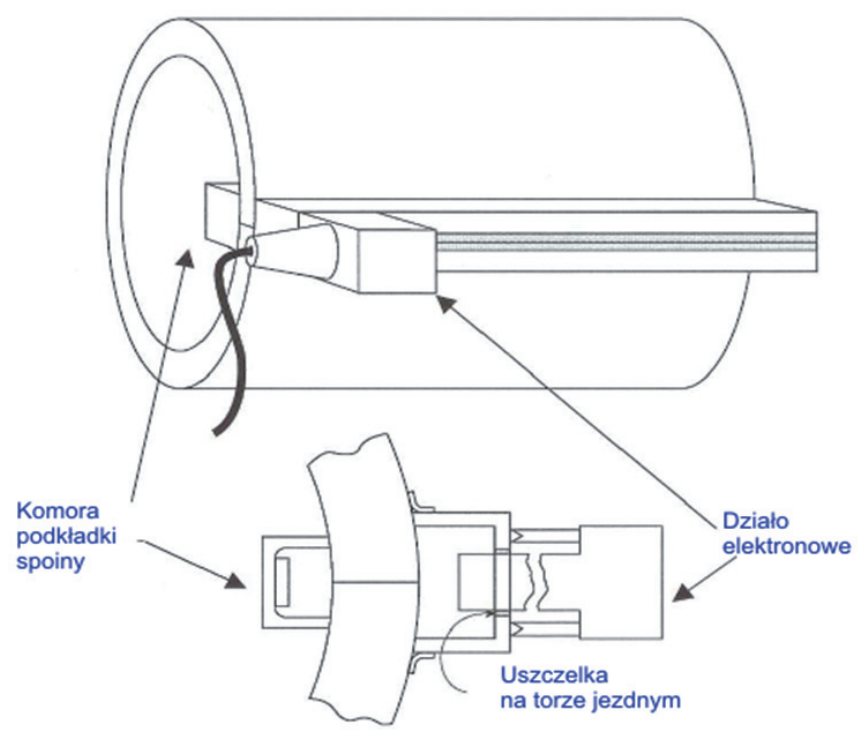

Rys. 9. Lokalne uszczelnienie, spawanie wzdłużne

Fig. 9. Local seal, longitudinal welding 


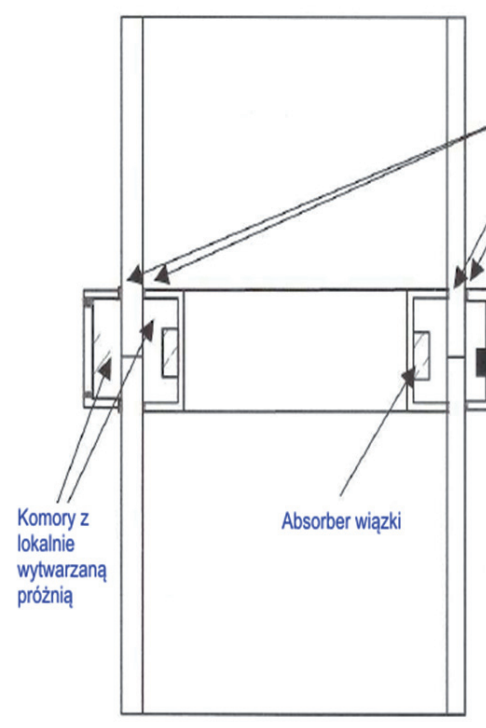

\section{Lokalnie}

Juszczelk

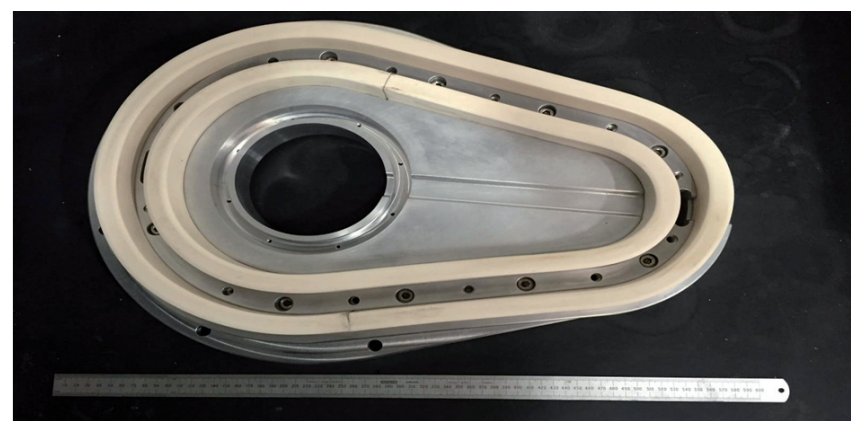

Rys. 11. Lokalne uszczelnienie, spawanie obwodowe Fig. 11. Local seal, orbital welding

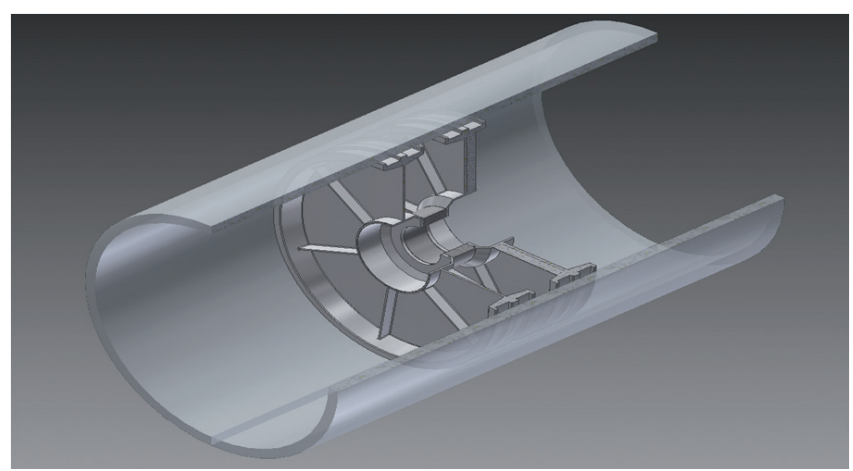

Rys. 12. Uszczelnienie wewnętrzne

Fig. 12. Internal seal

W 2015 roku w firmie CVE (Cambrige Vacuum Engineering) opracowano i wykonano pilotażowe stanowisko do spawania wzdłużnego metodą RPEBW. Stanowisko umożliwia spawanie wzdłużne rur o średnicy do $5000 \mathrm{~mm}$. $\mathrm{Na}$ rysunku 13 przedstawiono widok stanowiska w którego skład wchodzą: obrotnik rolkowy (rys. 14), działo elektronowe na torze jezdnym (rys. 16), obudowa chroniąca przed promieniowaniem $X$, (rys. 13), system sterujący (logika) (ze sterownikami PLC, system HMI (Human Machine Interface) oraz system bezpieczeństwa spełniający wymogi CE. Stanowisko pilotażowe umożliwia wykonywanie spoin wzdłużnych o długości 3000 mm i grubości ścianki do $65 \mathrm{~mm}$ jednym ściegiem. Na rysunku 15 przedstawiono zalecane sposoby przygotowania brzegów do spawania wzdłużnego RPEBW. Obecnie trwają prace nad zbudowaniem stanowiska do spawania obwodowego. Dla porównania czas wykonania spoiny wzdłużnej o długości 3000 mm i grubości ścianki $65 \mathrm{~mm}$ wynosi dla RPEBW - 18 minut, a wykonanie takiego samego złącza pod topnikiem (odmiana wąskoszczelinowa) wynosi ok. $300 \mathrm{~min}$. (15 razy dłużej) - rysunek 17 .

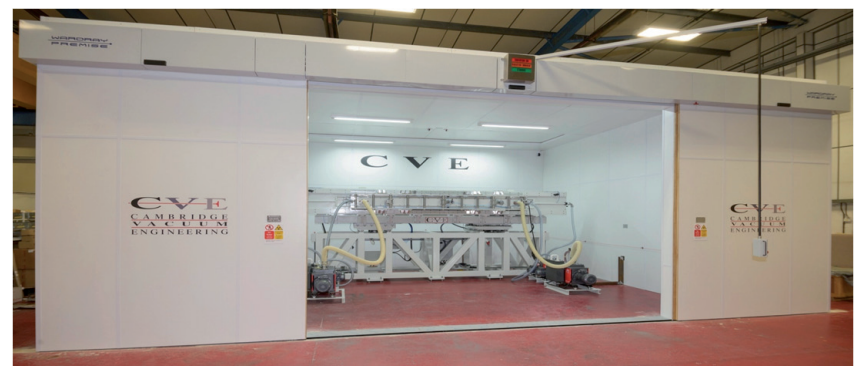

Rys. 13. Stanowisko pilotażowe do spawania wzdłużnego RPEBW Fig. 13. Pilot stadion for longitudinal welding

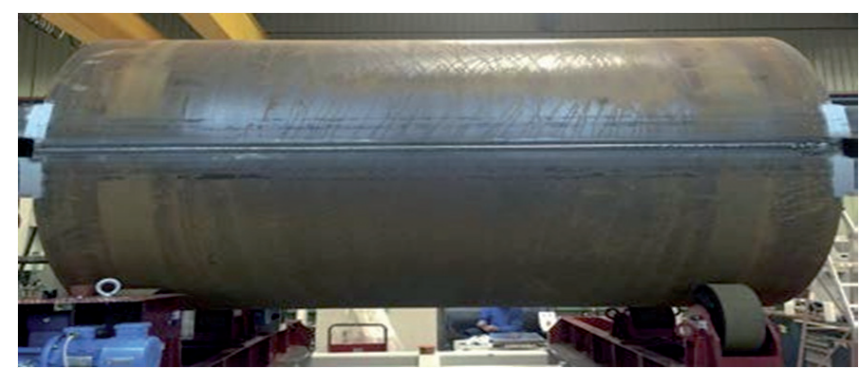

Rys. 14. Rura ze spoiną wzdłużną wykonaną metodą RPEBW Fig. 14. Pipe with longitudinal weld made with RPEBW method
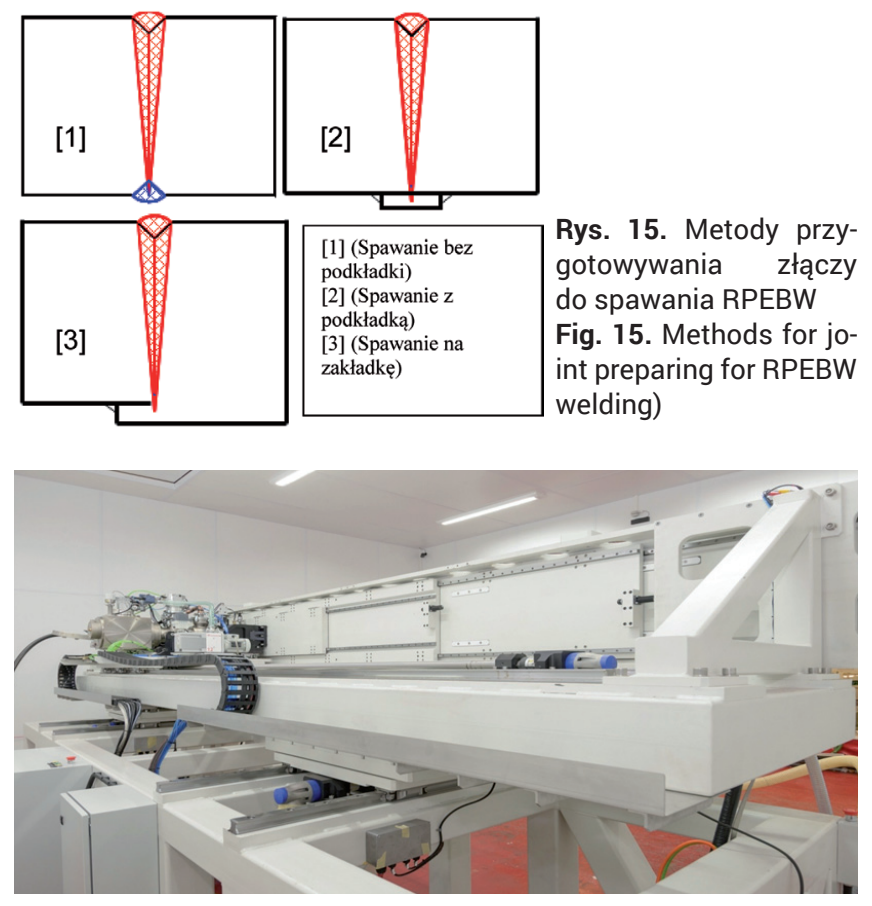

Rys. 16. Działo elektronowe na torze jezdnym

Fig. 16. Electron canon on gantry)
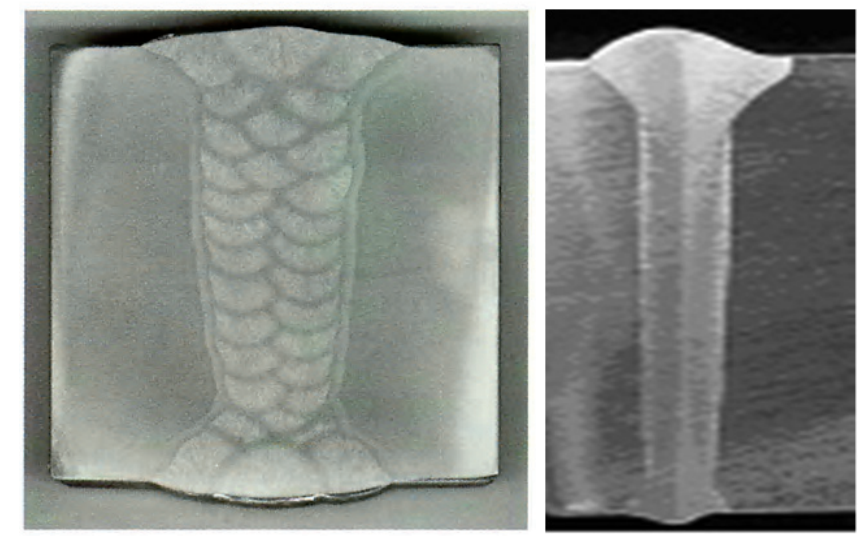

Rys. 17. Porównanie spawania łukiem krytym (odmiana wąskoszczelinowa) ze spawaniem RPEBW

Fig. 17. Comparison between SAW welding < narrow gap type $>$ and RPEBW 
Testy i próby wykazały wyższość technologii RPEBW nad technologią spawaniem łukiem krytym- w tym przypadku technologia RPEBW jest ok. 15 razy wydajniejsza od spawania łukiem krytym SAW. Innym przykładem zastosowania technologii RPEBW jest koncepcja zastąpienia odkuwania

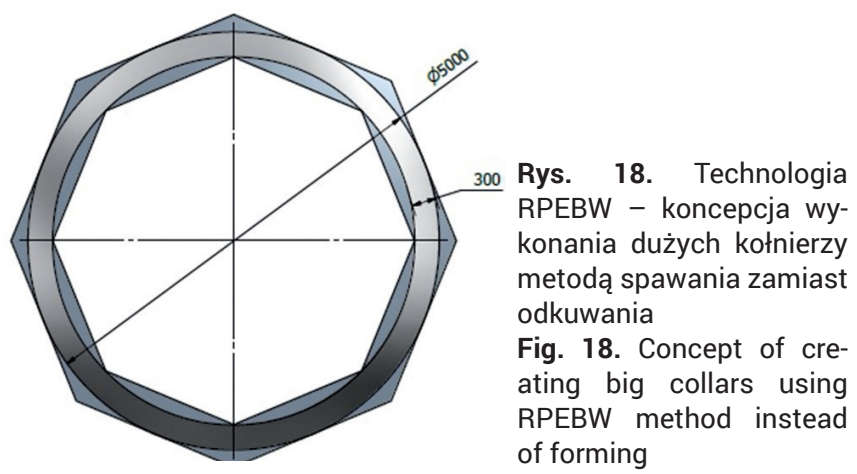

kołnierzy o grubości $50 \mathrm{~mm}$ i średnicach ponad $3000 \mathrm{~mm}$ spawaniem tą metodą (rys. 18,19).

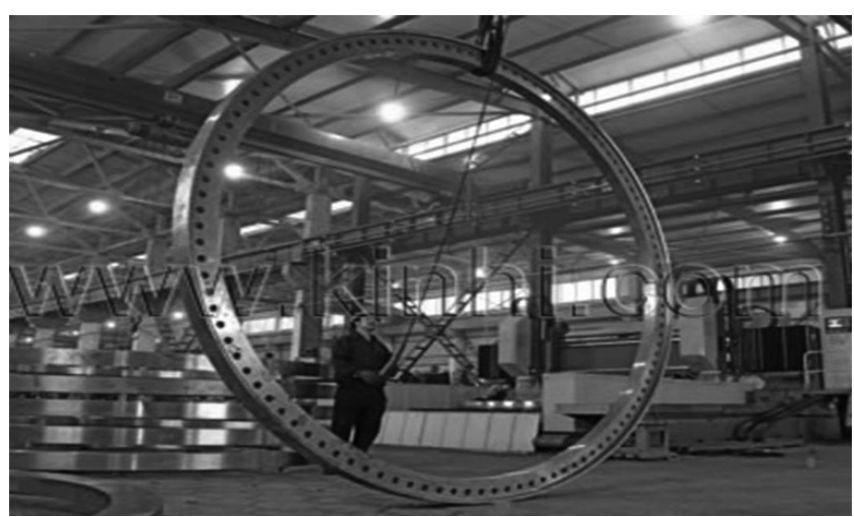

Rys. 19. Gotowy kołnierz wykonany metodą RPEBW (Finished collar made with RPEBW method)

\section{Wnioski}

Technologia spawania metodą RPEBW umożliwia zastosowanie spawania wiązką elektronów w miejscu budowy konstrukcji wielkogabarytowych

2. Metoda RPEBW jest obecnie najbardziej wydajną i najekonomiczniejszą w świecie technologią spawania rur i blach o grubościach ścianek powyżej $40 \mathrm{~mm}$ stali i innych metali gdyż:

- Jest 10 do 15 razy szybsza od spawania łukiem krytym pod topnikiem (SAW)

- Nie wymaga ukosowania a jedynie dopasowania elementów na styk

- Nie wymaga kosztownego podgrzewania elementów przed spawaniem

- Nie wymaga stosowania materiałów dodatkowych: drutów, topników

3. Wadą technologii RPEBW są bardzo wysokie koszty inwestycyjne.

\section{Literatura}

[1] Dworak J.: Spawanie wiązką elektronów - nowe możliwości . Materiały szkoleniowe Spawanie wiązką elektronów - Nowe możliwości, Gliwice 2015

[2] Węglowski M., Dworak J. Blacha S.: Materiały szkoleniowe Spawanie wiązką elektronów - Nowe możliwości, Gliwice 2015
[3] Philips A., Nowak M, Nowak M.: Spawanie wiązką elektronów przy zredukowanym ciśnieniu. Materiały szkoleniowe Spawanie wiązką elektronów - Nowe możliwości, Gliwice 2015

[4] Łukasz Leśniewski, Globalne i polskie tendencje w sektorze energetyki wiatrowej, Konferencja prasowa: Energetyka wiatrowa w Polsce 2015 